\title{
Impact of Different Furrow Spacing and Wetting Depths on Sunflower Production and Main Water Relations
}

\author{
Abd El-Aziz, M.M. Ragab, A.S. Antar and S. M. El-Barbary ${ }^{1}$
}

\begin{abstract}
Field experiments were conducted at Sakha Agric. Res. Station in the two successive seasons 2006 and 2007, to study the effect of different furrow- spacing and furrow wetting depths on yield and some water relations of sunflower. Three furrow spacing (i) Wide-spaced furrow $(90 \mathrm{~cm}$ apart) WSF, ii) alternate wide-spaced furrow with every-furrow $(60 \mathrm{~cm}$ apart) WSF/EF and iii) every-furrow $\mathrm{EF}$, in the main plots, in the used split plot design. The sub main plots were irrigation to a wetting depths 30,45 and $60 \mathrm{~cm}$.

The result showed that there were highly significant differences in the seed yield, seed weight/head, head numbers $/ \mathrm{m}^{2}$ and head diameter with various furrow spacing and wetting depths, in both seasons. Sunflower seed yield under WSF and WSF/EF were higher than EF by 35.09 and $14.92 \%$ in the first season and 32.39 and $13.69 \%$ in the second season. Also, the mean values of seed yield were $1037.3,908.2$ and $697.4 \mathrm{Kg} / \mathrm{fed}$. in the first season and 1151.1, 1007.08 and $781.4 \mathrm{Kg} /$ fed. in the second season, for 30, 45 and $60 \mathrm{~cm}$ wetting depths, respectively. The highest seeds yield was produced from interaction between wide spaced furrow and irrigation at a wetting depth of $30 \mathrm{~cm}$.
\end{abstract}

Wide spaced furrows and application of water to a wetting depth of $30 \mathrm{~cm}$ received the lowest amount of irrigation water. The highest values of field and crop water use efficiencies were achieved from interaction between wide spaced furrows and irrigation at a wetting depth of $30 \mathrm{~cm}$, while the lowest values were recorded from combination between every furrows and irrigation to a wetting depth of $60 \mathrm{~cm}$ in both seasons. The highest value of water application efficiency was found with wide spaced furrows. At the same time the water application efficiency was decreased with increasing the wetting depth. Widespaced furrows and wide-spaced furrows alternate with every-furrows saved irrigation water by 4.40 and $1.19 \%$ in the first season and 8.33 and $5.99 \%$ in the second season, respectively compared to every-furrows. Irrigation to a wetting depth of $30 \mathrm{~cm}$ saved irrigation water by 15.24 and $14.66 \%$ compared to a wetting depth of $60 \mathrm{~cm}$ in the first and second seasons, respectively. Also, $45 \mathrm{~cm}$ wetting depth saved 13.55 and $7.50 \%$ compared to $60 \mathrm{~cm}$ wetting depth in the first and second seasons, respectively.

Keywords: Irrigation, Furrow spacing, Wetting depth, Sunflower, Water relations.

\section{INTRODUCTION}

\footnotetext{
${ }^{1}$ Soils, Water and Environment Res. Inst., Agric. Res. Center Egypt. Received July 8, 2008, Accepted September 2, 2008
}

Agriculture in Egypt depends almost entirely on irrigation from the River Nile. Nearly $85 \%$ of the available supply is consumed by the agriculture sector (El-Kady and Sameh, 2003). The possibility to increase water supply is limited and conditioned. An available alternative is to increase irrigation efficiency by minimizing water losses. Economic irrigation requires proper and suitable irrigation scheduling to meet the ET crop and, to prevent salt accumulation in the soil profile. Improving the irrigation system constitutes the key element to achieve the national goal of increasing irrigation use efficiency (Kassab, 2003 and Abo Soliman et al, 2005)

Wide-spaced furrow irrigation is the application of irrigation water to furrows separated by more than 2.5 $\mathrm{m}$, and it requires a medium- to fine- textured soil where the potential for lateral movement of water is high (Stone et al., 1985 and Tsegaye et al., 1993). Several rows of crop may intervene between irrigated furrows. Results indicated a higher yield potential for widespaced furrow irrigation than every-furrow irrigation (Tsegaye et al., 1993). After several years of studies, wide-spaced furrow irrigation was shown to produce a yield vs. water input curve with $40 \%$ greater slope than every-furrow irrigation (Stone et al., 1985). Shafiq et al., (2002) studied the effect of furrow-beds on root development and function is by far the most important role of furrow-bed in crop development.

Sunflower is considered one of the most promising oil crops in Egypt. It is proposed to close up the gap of oil consumption by planting sunflower. Sunflower has the ability to exploit a large rooting volume for soil water. Fields for sunflower production should be selected from those with the greater water holding capacity and soils without layers that may restrict rooting depth (NDSU, 1995). Hodges et al. (1989) reported that evapotranspiration decreased by increasing furrow spacing. Rivelli and Perniola, (1997) reported that sunflower seed yield was highest when irrigation was done to replace 60 to $100 \%$ of evapotranspiration. Kassab, (2003) recommended that, lowering the traditional depth of irrigation water which is practiced by farmers of North Delta, from $7.5 \mathrm{~cm}$ to $5.0 \mathrm{~cm}$ along with increasing the $60-\mathrm{cm}$ distance between furrows which involves widening of soil ridges having 3-plant 
rows instead of 1-plant row per ridge increases yield and decreases water application as well as water efficiency.

Efficient use of irrigation water not only saved available water supplies but also have a direct impact on alleviating waterlogging and salinity. The losses of water under flood and basin irrigation are around 2540\% (World Bank, 1997). Mahal et al.,(1998) found that $40 \%$ depletion of available moisture resulted in a water saving of $8.2 \mathrm{~cm}(12.2 \%)$ and gave higher WUE of $31.2 \mathrm{~kg} / \mathrm{ha} . \mathrm{cm}$ as compared with $20 \%$ depletion of available moisture without any adverse effect on plant growth and seed yield. Shafiq et al., (2003) indicated that under furrow-bed on the average, there was $29 \%$ less, irrigation depths with $42 \%$ greater grain yield compared to basin. The water use efficiency was $68 \%$ greater with $35 \%$ less weed infestation under furrow-bed compared to basin.

The aim of this work was to evaluate three furrow spacing and three wetting depths of irrigation water on productivity of sunflower plants and to examine some water relations.

\section{MATERIALS AND METHODS}

Experimental Farm of Sakha Agric. Res. Station, during the summer seasons (2006 and 2007).To evaluate three furrow spacing methods and three wetting depths on productivity and some water relations of sunflower plants. The experiment was in a split-plot design with four replicates. The main plots were randomly assigned to three furrow spacing and the sub-plots were three wetting depths as follows:

\section{Main plots (furrow spacing):}

F1: Wide-spaced furrow (WSF)(90cm apart) and $100 \mathrm{~m}$ length.

F2: Alternate wide-spaced furrow $(90 \mathrm{~cm})$ with every furrow $(60 \mathrm{~cm})(\mathrm{WSF} / \mathrm{EF})$.

F3: Every-furrow (60cm apart) (EF).

\section{Sub-plots (wetting depths):}

D1: Irrigation to a wetting depth of $30 \mathrm{~cm}$.

D2: Irrigation to a wetting depth of $45 \mathrm{~cm}$.

D3: Irrigation to a wetting depth of $60 \mathrm{~cm}$.

Sunflower (Helianthus annus L.) was planted on $17^{\text {th }}$ of June in 2006 and $25^{\text {th }}$ of June in 2007. Seeds were planted in two rows for the WSF. Phosphorus in the form of Ca-superphosphate $\left(\begin{array}{lll}15.5 \% & \mathrm{P}_{2} \mathrm{O}_{5}\end{array}\right)$ was added through preparation of the soil. Nitrogen fertilizer in the form of urea was side dressed at a rate of $45 \mathrm{Kg} \mathrm{N} / \mathrm{fed}$ in two doses before the first irrigation and the second irrigation. The different agricultural practices were done as recommended through the two growing season. The irrigation date took place when $50 \%$ of available soil moisture was depleted. Two to three days before the predicted date of irrigation, soil moisture samples from $0-15,15-30,30-45$ and $45-60 \mathrm{~cm}$ depths were collected to determine soil moisture deficit. Volumetric moisture contents of available water in root zone were used to estimate the depth of net irrigation. Sunflower was harvested on September, 18, 2006 and September, 28, 2007 from all treatments. Yield components during the two growing seasons and seed yield were determined.

\section{Amount of water applied}

The irrigation water applied was measured by using a calibrated set of cut-throat flume $(20 \times 90 \mathrm{~cm})$, Early (1975).

Water consumptive use (C.U.): was calculated according to (Israelson and Hansen,1962) as follows:

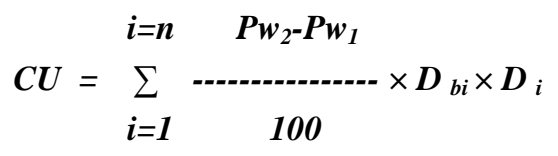

Where:

C.U. : Water consumptive use in $\mathrm{cm}$.

$P w_{2}$ : Soil moisture percent after irrigation in the $\mathrm{i}^{\text {th }}$ layer.

$P w_{l}$ : Soil moisture percent before the next irrigation in the $\mathrm{i}^{\text {th }}$ layer.

$D_{b i}$ : Bulk density $\mathrm{g} / \mathrm{cm}^{3}$ of the $\mathrm{i}^{\text {th }}$ layer of the soil.

$D_{i}$ : Depth of the $\mathrm{i}^{\text {th }}$ layer of the soil, $\mathrm{cm}$.

$i$ : Number of soil layers sampled in the root zone depth (D).

Field water use efficiency (FWUE) is the weight of marketable crops produced per the volume unit of applied irrigation water: was calculated as follows:

FWUE $\left(\mathrm{kg} / \mathrm{m}^{3}\right)=$ Yield $(\mathrm{kg} / \mathrm{fed}$.$) / Amount of water$ applied ( $\mathrm{m}^{3} /$ fed.)

Crop water use efficiency (C.W.U.E.) is the weight of marketable crops produced per the volume unit of water consumed by plants: was calculated by using formula:

CWUE $\left(\mathbf{k g} / \mathbf{m}^{\mathbf{3}}\right)=$ Yield $(\mathrm{kg} / \mathrm{fed}$.$) / Seasonal water$ consumptive use $\left(\mathrm{m}^{3} / \mathrm{fed}\right.$ ), (Doorenbos and Pruitt, 1977).

Water application efficiency, is the ratio of the average depth of irrigation water infiltrated and stored in the root zone to the average depth of irrigation water applied, Michael (1978).

Irrigation water losses: consists of deep percolation and runoff:

Loss $\%=100-$ Water application efficiency $\%$

Soil bulk density was determined according to Klute (1986) and other soil properties were analyzed before planting and are presented in Table(1). Statistical 
Table1. Main physical properties and salinity of the soil

\begin{tabular}{|c|c|c|c|c|c|c|c|c|c|c|}
\hline \multirow{2}{*}{$\begin{array}{c}\text { Soil } \\
\text { depth } \\
(\mathrm{cm})\end{array}$} & \multicolumn{3}{|c|}{ Particle size distribution } & \multirow{2}{*}{ Texture } & \multirow{2}{*}{$\begin{array}{l}\text { B.I.R. } \\
(\mathbf{c m} / \mathbf{h r})\end{array}$} & \multirow{2}{*}{$\begin{array}{c}\text { Bulk } \\
\text { density } \\
\mathbf{M g} / \mathbf{m 3}\end{array}$} & \multirow{2}{*}{$\underset{(\mathbf{d S} / \mathbf{m})}{\mathbf{E C}}$} & \multicolumn{3}{|c|}{$\begin{array}{c}\text { Soil moisture } \\
\text { characteristics }\end{array}$} \\
\hline & Sand\% & Silt $\%$ & Clay \% & & & & & $\begin{array}{c}\text { FC } \\
\%\end{array}$ & $\begin{array}{c}\text { WP } \\
\%\end{array}$ & $\begin{array}{c}\text { AW } \\
\%\end{array}$ \\
\hline $0-15$ & 9.14 & 33.75 & 57.11 & Clayey & \multirow{3}{*}{0.9} & 1.14 & 1.3 & 40.4 & 22.02 & 18.38 \\
\hline $\begin{array}{l}15-30 \\
30-45\end{array}$ & $\begin{array}{l}9.55 \\
8.98\end{array}$ & $\begin{array}{l}33.14 \\
38.49\end{array}$ & $\begin{array}{l}57.31 \\
52.53\end{array}$ & $\begin{array}{l}\text { Clayey } \\
\text { Clayey }\end{array}$ & & $\begin{array}{l}1.18 \\
1.26\end{array}$ & $\begin{array}{l}1.3 \\
1.5\end{array}$ & $\begin{array}{l}42.95 \\
36.25\end{array}$ & $\begin{array}{c}23.32 \\
19.7\end{array}$ & $\begin{array}{l}19.63 \\
16.55\end{array}$ \\
\hline $45-60$ & 9.21 & 39.05 & 51.74 & Clayey & & 1.26 & 1.5 & 37.67 & 20.69 & 17.07 \\
\hline
\end{tabular}

EC=Electrical conductivity $\mathrm{BIR}=\mathrm{Basic}$ infiltration rate $\mathrm{FC}=$ Field capacity $\mathrm{WP}=$ Wilting point $\mathrm{AW}=$ Available water (on weight basis).

analysis: Data are subjected to statistical analysis according to Snedecor and Cochran (1980).

\section{RESULTS AND DISCUSSIONS}

\section{Furrow spacing methods:}

Table(2) showed that there were highly significant differences in the seed yield, seed weight/head, head number $/ \mathrm{m}^{2}$ and head diameter with various furrow spacing methods (WSF, WSF/EF and EF) in both seasons. sunflower seed yield under WSF and WSF/EF planting were higher than EF planting, respectively by 35.09 and $14.92 \%$ in the first season and 32.39 and $13.69 \%$ in the second season. The values were higher under WSF and WSF/EF planting than EF planting, respectively by 13.56 and $5.79 \%$ for seed weight/head, 39.10 and $13.46 \%$ for head number $/ \mathrm{m}^{2}, 7.35$ and $3.52 \%$ for head diameter in the first season. The corresponding values were 13.95 and $6.09 \%, 40.88$ and $18.25 \%, 3.95$ and $2.66 \%$ in the second season, respectively. The increase in yield under wide-spaced furrow (WSF) may be attributed to better root environment which encouraged plant height, other yield components and consequently seed yield. Similar trend were obtained by Tsegaye et al. (1993) and Kassab (2003) they reported that wide-spaced furrow irrigation(WSF) tended to produce a higher yield than every-furrow irrigation $(\mathrm{EF})$.

\section{Wetting depths:}

Table(3) showed that there were highly significant increases in the seed yield, seed weight/head, head number $/ \mathrm{m}^{2}$ and head diameter with different wetting depth $(30 \mathrm{~cm}, 45 \mathrm{~cm}$ and $60 \mathrm{~cm}$ depth) for both seasons. The mean values of seed yield were 1037.3, 908.2 and $697.4 \mathrm{~kg} / \mathrm{fed}$. in the first season while, it were 1151.1 , 1007.08 and $781.4 \mathrm{~kg} / \mathrm{fed}$. in the second season, for 30,45 and $60 \mathrm{~cm}$ wetting depths, respectively. Results indicated that, under irrigation to wetting depths of $30 \mathrm{~cm}$ and $45 \mathrm{~cm}$ the increase were 11.85 and $5.11 \%$ for seed weight/head, 58.45 and $28.78 \%$ for head number $/ \mathrm{m}^{2}, 8.27$ and $3.62 \%$ for head diameter compared to $60 \mathrm{~cm}$ wetting depth, respectively in the first season. The corresponding values were 14.59 and $7.41 \%, 63.11$ and $39.34 \%, 5.16$ and $3.82 \%$ in the second season, respectively. These decrements in sunflower production could be attributed mass flux of water and fertilizers could be happened under $60 \mathrm{~cm}$ wetting depth. On the other hand, under $30 \mathrm{~cm}$ wetting depth, the withdrawn of fertilizers was decreased. Similar results were obtained by El-Hamdi and Knany (2000) and Kassab (2003)

\section{Table2. Effect of furrow spacing methods on yield characteristics of sunflower plants}

\begin{tabular}{|c|c|c|c|c|}
\hline Furrow spacing & Seed yield (kg/fed.) & $\begin{array}{c}\text { Seed weight per } \\
\text { head (gm) }\end{array}$ & Head number per $\mathbf{m}^{2}$ & $\begin{array}{c}\text { Head diameter } \\
(\mathrm{cm})\end{array}$ \\
\hline \multicolumn{5}{|c|}{ First season (2006) } \\
\hline WSF & 1020.04 & 140.05 & 2.17 & 24.09 \\
\hline WSF/EF & 867.76 & 130.47 & 1.77 & 23.23 \\
\hline $\mathrm{EF}$ & 755.10 & 123.33 & 1.56 & 22.44 \\
\hline F-test & $* *$ & $* *$ & $* *$ & $* *$ \\
\hline L.S.D. 0.05 & 39.12 & 4.38 & 0.15 & 0.75 \\
\hline L.S.D. 0.01 & 59.28 & 6.67 & 0.23 & 1.14 \\
\hline \multicolumn{5}{|c|}{ Second season $(2007)$} \\
\hline WSF & 1124.52 & 146.44 & 1.93 & 25.78 \\
\hline WSF/EF & 965.63 & 136.34 & 1.62 & 25.46 \\
\hline $\mathrm{EF}$ & 849.37 & 128.51 & 1.37 & 24.80 \\
\hline F-test & ** & $* *$ & ** & $* *$ \\
\hline L.S.D. 0.05 & 57.56 & 3.20 & 0.18 & 0.52 \\
\hline L.S.D. 0.01 & 83.73 & 4.85 & 0.26 & 0.79 \\
\hline
\end{tabular}


Table3. Effect of different wetting depths on yield characteristics of sunflower plants

\begin{tabular}{|c|c|c|c|c|}
\hline Furrow spacing & Seed yield (kg/fed.) & $\begin{array}{l}\text { Seed weight per } \\
\text { head (gm) }\end{array}$ & Head number per & $\begin{array}{l}\text { Head diameter } \\
(\mathrm{cm})\end{array}$ \\
\hline \multicolumn{5}{|c|}{ First season (2006) } \\
\hline $30 \mathrm{~cm}$ & 1037.03 & 138.98 & 2.25 & 24.22 \\
\hline $45 \mathrm{~cm}$ & 908.2 & 130.61 & 1.83 & 23.18 \\
\hline $60 \mathrm{~cm}$ & 697.4 & 124.26 & 1.42 & 22.37 \\
\hline F-test & ** & $* *$ & $* *$ & $* *$ \\
\hline L.S.D. 0.05 & 31.63 & 3.46 & 0.12 & 0.50 \\
\hline L.S.D. 0.01 & 43.34 & 4.74 & 0.16 & 0.68 \\
\hline \multicolumn{5}{|c|}{ Second season (2007) } \\
\hline $30 \mathrm{~cm}$ & 1151.10 & 146.37 & 1.99 & 25.88 \\
\hline $45 \mathrm{~cm}$ & 1007.08 & 137.19 & 1.70 & 25.55 \\
\hline $60 \mathrm{~cm}$ & 781.34 & 127.73 & 1.22 & 24.61 \\
\hline F-test & $* *$ & $* *$ & $* *$ & $* *$ \\
\hline L.S.D. 0.05 & 43.60 & 4.10 & 0.16 & 0.58 \\
\hline L.S.D. 0.01 & 59.73 & 5.62 & 0.22 & 0.79 \\
\hline
\end{tabular}

\section{Interactions:}

The interaction between furrow spacing and different wetting depths (Table 4) data showed that there were significant differences on sunflower seed yield. The highest seed yield were found under combination of wide-spaced furrows with $30 \mathrm{~cm}$ wetting depth followed by, wide-spaced furrows+furrow with $45 \mathrm{~cm}$ wetting depth and furrow with $30 \mathrm{~cm}$ wetting depth, while the lowest seed yield were under furrow with $60 \mathrm{~cm}$ wetting depth in both season. The interaction between widespaced furrows and $30 \mathrm{~cm}$ wetting depth resulted in the highest values of seed weight/head, 150.7 and $159.0 \mathrm{~g}$ and head number $/ \mathrm{m}^{2}, 2.48$ and 2.37 head $/ \mathrm{m}^{2}$ in the first and second seasons, respectively.

Water relations and field geometry:

Total amount of water applied to sunflower plants in both seasons was shown in Table (5). It is noticed that,

Table 4. Interaction between furrow spacing and different wetting depths on sunflower yield characteristics

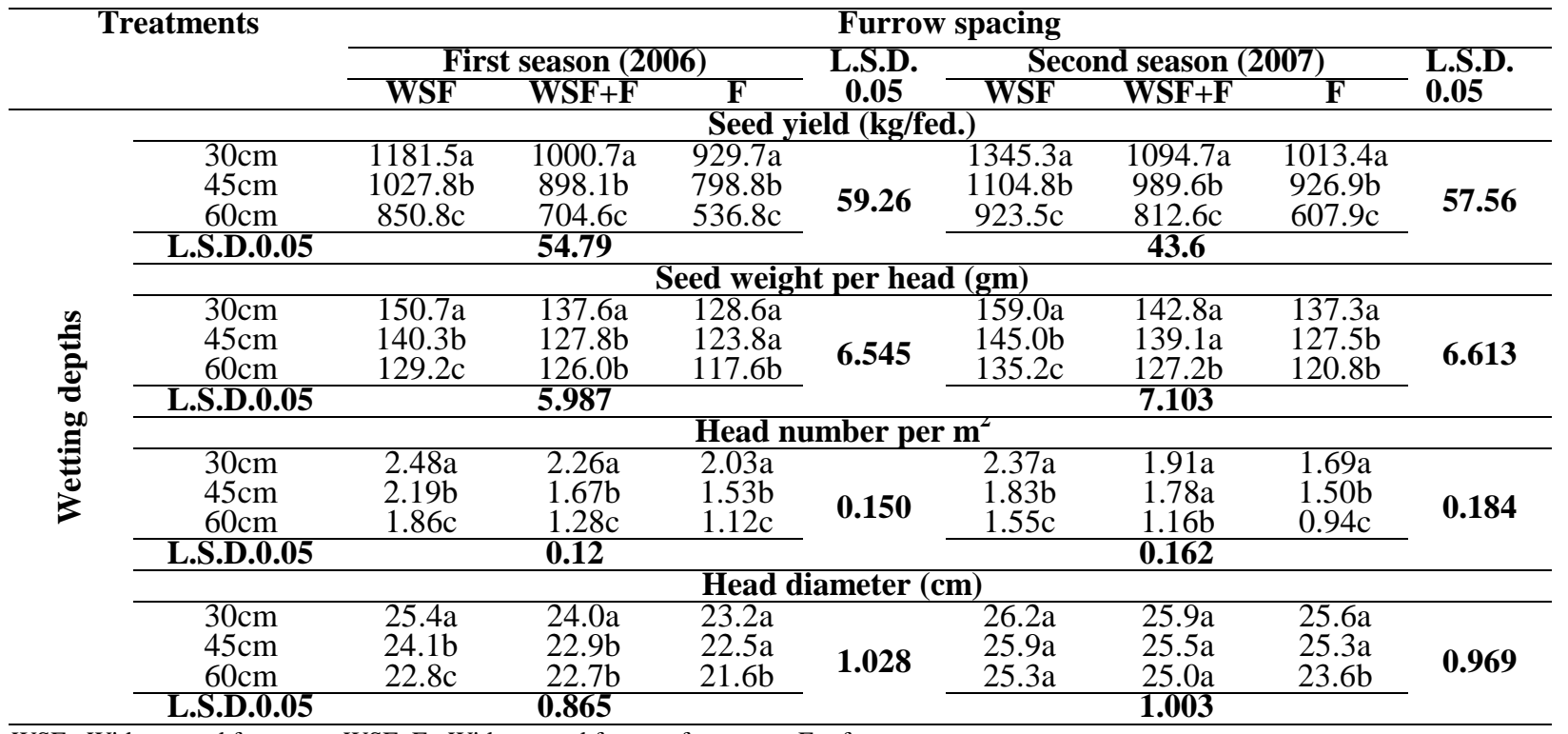

$\mathrm{WSF}=$ Wide-spaced furrow

$\mathrm{WSF}+\mathrm{F}=$ Wide-spaced furrow + furrow
WSF planting and $30 \mathrm{~cm}$ wetting depth received the lowest amount of irrigation water. While, F planting and $60 \mathrm{~cm}$ wetting depth received the highest amount of irrigation water but, $\mathrm{WSF}+\mathrm{F}$ and $45 \mathrm{~cm}$ wetting depth display an intermediate case. The average amount of water applied on both seasons were 2702.5, 2846.5 and $3089.4 \mathrm{~m}^{3} /$ fed.for WSF, WSF+F and $\mathrm{F}$ methods, respectively. The corresponding amounts were 2451.2, 2737.0 and $3450.3 \mathrm{~m}^{3} /$ fed.for wetting depth of $30 \mathrm{~cm}$, $45 \mathrm{~cm}$ and $60 \mathrm{~cm}$, respectively. The overall less irrigation water applied under wide-spaced furrow compared to other methods may be attributed to less areas wetted and soil surface. configuration. Similar results were obtained by Kassab (2003) and Shafiq et al.(2003).

Water stored and consumptive use $\left(\mathrm{m}^{3} / \mathrm{fed}\right.$.) generally behaved the same trend of total water applied. 
Table 5. Some water relations as affected by various furrow spacing and wetting depths under sunflower plants

\begin{tabular}{|c|c|c|c|c|c|c|c|}
\hline Treatments & $\begin{array}{c}\text { Water } \\
\text { applied } \\
\text { (m/fed.) }\end{array}$ & $\begin{array}{c}\text { Water } \\
\text { storred } \\
\text { ( } \mathbf{m}^{3} / \text { fed.) }\end{array}$ & $\underset{\left(\mathbf{m}^{3} / \text { fed. }\right)}{\text { C.U. }}$ & $\begin{array}{c}\text { C.W.U.E.E. } \\
\text { water) }\end{array}$ & $\begin{array}{c}\text { F.W.U.E. } \\
\text { (kg/m } \\
\text { water) }\end{array}$ & $\begin{array}{c}\text { Water } \\
\text { application } \\
\text { efficiency } \\
\%\end{array}$ & Losses \% \\
\hline Furrow spacing & & & First season & & & & \\
\hline WSF & 2680.9 & 2074.5 & 2061.9 & 0.38 & 0.49 & 77.38 & 22.62 \\
\hline $\mathrm{WSF}+\mathrm{F}$ & 2792.3 & 2071.1 & 2103.9 & 0.31 & 0.41 & 74.17 & 25.83 \\
\hline $\mathrm{F}$ & 2993.2 & 2184.3 & 2221.8 & 0.25 & 0.34 & 72.98 & 27.02 \\
\hline \multicolumn{8}{|l|}{ Wetting depths } \\
\hline $30 \mathrm{~cm}$ & 2418.9 & 1968.5 & 1995.4 & 0.42 & 0.51 & 81.39 & 18.61 \\
\hline $45 \mathrm{~cm}$ & 2662.3 & 2121.9 & 2085.5 & 0.28 & 0.36 & 79.70 & 20.30 \\
\hline $60 \mathrm{~cm}$ & 3385.2 & 2239.2 & 2306.8 & 0.26 & 0.38 & 66.15 & 33.85 \\
\hline \multicolumn{3}{|l|}{ Furrow spacing } & \multicolumn{5}{|c|}{ second season } \\
\hline WSF & 2724.2 & 2084.5 & 2100.5 & 0.41 & 0.54 & 76.52 & 23.48 \\
\hline $\mathrm{WSF}+\mathrm{F}$ & 2900.7 & 2151.6 & 2092.1 & 0.33 & 0.46 & 74.18 & 25.82 \\
\hline $\mathrm{F}$ & 3185.7 & 2172.2 & 2186.8 & 0.27 & 0.39 & 68.19 & 31.81 \\
\hline \multicolumn{8}{|c|}{ Wetting depths } \\
\hline $30 \mathrm{~cm}$ & 2483.4 & 2008.3 & 2023.6 & 0.46 & 0.57 & 80.87 & 19.13 \\
\hline $45 \mathrm{~cm}$ & 2811.7 & 2072.5 & 2110.1 & 0.36 & 0.48 & 73.71 & 26.29 \\
\hline $60 \mathrm{~cm}$ & 3515.5 & 2327.5 & 2245.8 & 0.22 & 0.35 & 66.21 & 33.79 \\
\hline
\end{tabular}

$\mathrm{WSF}=$ Wide-spaced furrow $\mathrm{WSF}+\mathrm{F}=$ Wide-spaced furrow+furrow Field and crop water use efficiencies $\left(\mathrm{kg} / \mathrm{m}^{3)}\right.$ for seed yield (Table5) generally take the same trend; the highest values were achieved under WSF method and $30 \mathrm{~cm}$ wetting depth, while the lowest values were found under $F$ method and $60 \mathrm{~cm}$ wetting depth, in both seasons. In this regards, Hodges et al. (1989) compared the amount of water used by wide-spaced furrow (WSFI) and everyfurrow irrigation (EFI) using grain sorghum in rows $830 \mathrm{~m}$ long and an irrigation interval of 9-d. The WSFI received one-half as much water as the EFI and still produced a reasonable yield. Also, Tsegaye et al. (1993) indicated that the WUE of plants was higher for the wide-spaced furrow irrigation than every furrow irrigation.

With regard to water application efficiency, it is worthy to mention that the WSF method achieved the highest values followed by WSF+F, while the lowest value was achieved under $\mathrm{F}$ method in both seasons. Concerning the irrigation to different wetting depths, it is clear that water application efficiency decreased with increasing wetting depth.

Data depicted in Table (5) showed that the irrigation water losses at on farm level had almost the opposite trend to that encountered with water application efficiency. Results revealed that, WSF and $\mathrm{WSF}+\mathrm{F}$ could save irrigation water by 4.40 and $1.19 \%$ in the first season and 8.33 and $5.99 \%$ in the second season, respectively compared to every furrow method, this may be attributed to that WSF planting wet only halfway across the surface of the bed at each irrigation, and the remainder of the surface remained dry. This mode
$\mathrm{F}=$ furrow

evidently reduced the evaporation from soil by keeping the surface drier. With the F method, wetting occurred from the furrows on both sides of the beds and wet across the entire bed. This wetting behavior kept the surface wetter longer. In this concern, Tsegaye et al. (1993) showed that the evaporation from soil was $30 \mathrm{~mm}$ higher for every-furrow irrigation than for wide-spaced furrow irrigation. Irrigation to $30 \mathrm{~cm}$ wetting depth saved irrigation water compared to $60 \mathrm{~cm}$ wetting depth by 15.24 and $14.66 \%$ for first and second seasons, respectively. Also, $45 \mathrm{~cm}$ wetting depth saved 13.55 and $7.50 \%$ than $60 \mathrm{~cm}$ wetting depth in the first and second seasons, respectively. Similar results were obtained by Mahal et al., (1998).

\section{REFERENCES}

Abo Soliman, M.S.M.; H.A. Shams El-Din; M.M. Saied; S. M. El-Barbary; M.A.Ghazy; M.E. El-Shahawy; E.A.Gazia and M.A. Abo El-Soud (2005). Maximizing conveyance efficiency through lining marwas at on-farm level in old lands of Egypt. J. Agric. Sci. Mansoura Univ., 30(10):6371-6383.

Doorenbos, J and W.O.Pruitt (1977). Guideline of predicting crop water requirements. Irrigation and Drainage Paper (24). FAO, Rome.

Early, A.C. (1975). Irrigation Scheduling for wheat in Punjab Cento Sci. prog. Optimum use of water in Agric. Rpt. 17 lyallpur, Pakistan 3-5 March 1975, pp. 115-127.

El-Hamdi, Kh.M. and R. El. Knany (2000). Influence of irrigation and fertilization on water use and efficiencies on saline soil. J. Agric. Sci. Mansoura Univ., 25(6): 37113720 . 
Hodges, M. E.; J. F. Stone and H. E. Reeves (1989). Yield variability and water use in wide-spaced furrow irrigation. Agric. Water Manage. 16: 15-23.

Israelsen O.W and V.E.Hansen (1962). Irrigation principles and practices, $3^{\text {rd }}$ Edit. John willey and Sons, Inc. New York.

Kassab, (2003). Towards effective water management for some field crops in North Nile Delta Region. Ph. D. Thesis, Fac. Agric. Moshtohor, Zagazig Univ., Egypt.

Klute, A. (1986). Water retention: laboratory methods. In: A. Koute (ed.), Methods of soil analysis, Part 1. $2^{\text {nd }}$ ed. Agron. Monogr. 9, ASA, Madison, WI. USA, pp. 635660.

Mahal, S. S.; Uppalm H. S. and Mankotia, B. S. (1998). Performance of spring sunflower (Helinthus annuus L.) under different levels of soil moisture regime and nitrogen. Environment and Ecology. 16 (3): 599-602.

Michael (1978). Irrigation theory and practices. Vikas Publishing House, New Delhi.

Mona El-Kady and Sameh, A. (2003). Water Resources Management Policies in Egypt. Astory of Success. Water Science, the $34^{\text {th }}$ issue, October, 2003.

North Dakota State University (NDSU) (1995). Sunflower Production-Hybrid Selection and Production Practices. WWW.ag. ndsu.edu
Rivelli, A. R. and Perniola, M. (1997). Effect of irrigation regime and sowing date on some sunflower cultivars in three areas of Basilicata. Journal of production Agriculture. 10 (1): 123-129.

Snedercor, G.W. and W.G. Cochran (1980). "Statistical Methods" $7^{\text {th }}$ ed., 225-330. Iowa state Univ., Press., Ames., Iowa, USA.

Shafiq, M.; I. Hassan and Z. Hussain (2003). Maize crop production and water use efficiency as affected by planting methods. Asian J. Plant Sci., 2 (1): 141-144.

Shafiq, M.; I. Hassan; M. Khan; Z. Hussain and S. Ahmad, (2002). Maize and wheat crop production as influenced by basin and furrow bed irrigation methods. J. Eng. App. Sci. (Accepted for publication).

Stone, J.F.; H. E. Reeves and T. Tsegaye (1985) . Irrigation water requirements under wide-spaced furrow irrigation. P. 309-317. In C.G. Keyes, Jr. (ed.) Development and management aspects of irrigation and drainage systems. Proc. ASCE Specialty Conf., San. Antonio, TX. 16-19 July 1985, Irrig. Drain. Div., Am. Soc. Civ. Eng., New York.

Tsegaye,T.; J.F.Stone and H.E.Reeves (1993). Water use characteristics of wide-spaced furrow irrigation. Soil Sci. Soc. Am. J. 57: 240-245.

World Bank, (1997). Staff appraised report. Pakistan National Drainage Project. Rural Development Sector Management Unit. South Asia Region. Report No. 15310, pak., pp: 3-4. 


\title{
الملخص العربي
}

\section{تأثير أنماط الزراعة بالخطوط عمق الابتلال على العلاقات المائية الأساسية}

\author{
والإنتاجية لنبات عبادالشمس

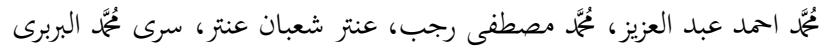

أجريت تجربتان حقليتان في مزرعة معطة البحوث الزراعية بسخا 45، 60 سم على على التوالى. تحققت أعلى إنتاجية من البذور نتيجة

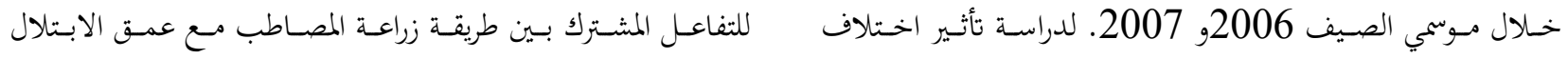

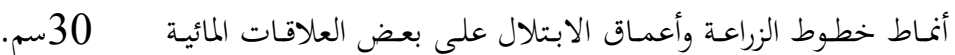

أن طريقة زراعة المصاطب و عمق الابتلال 30سم استقبلت أقل

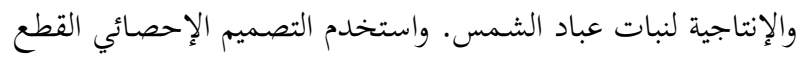

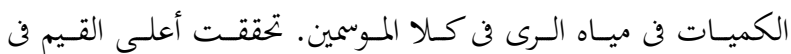

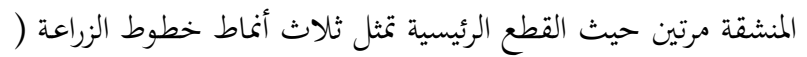

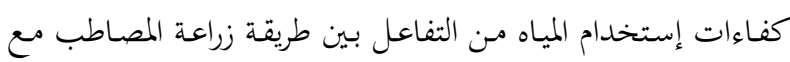

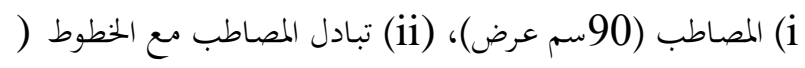

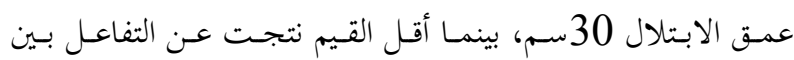

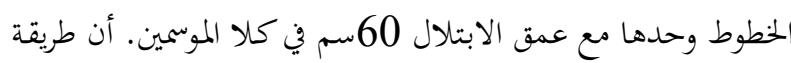

زراعة المصاطب حققت أعلى القيم فن كفاءة الرى.

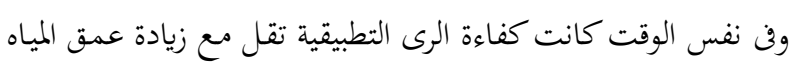

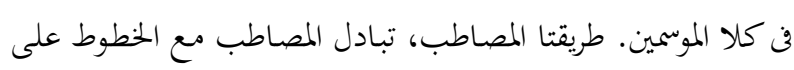

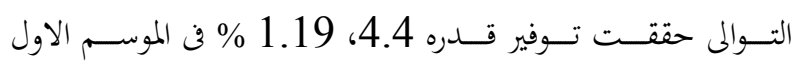

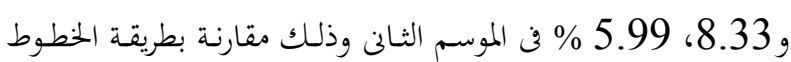

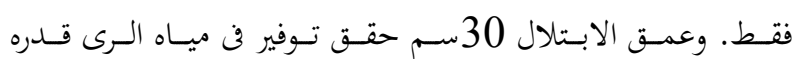
15.24، 14.66\% فن الموسـم الاول والثـانى على التوالى مقارنـة

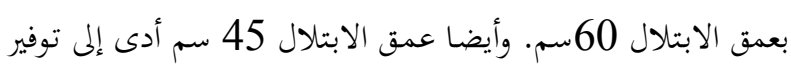

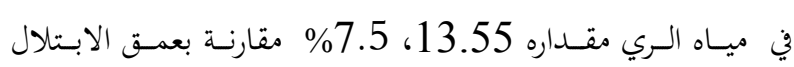
60سم عرض)، (1ii) الخطوط وحدها. القطع الشقية تمثل أعماق

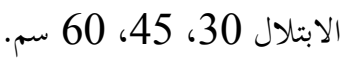

وتوضـح النتائج أن أنمـاط الزراعـة بالخطـوط وأعمـاق الابتـلال

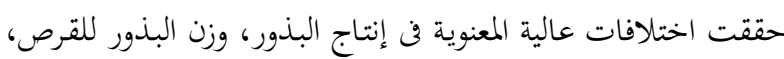

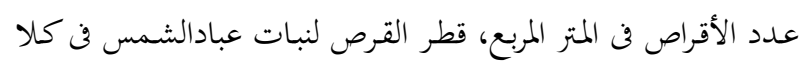

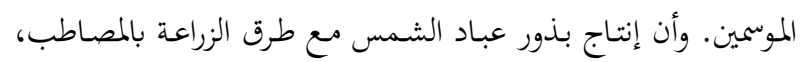

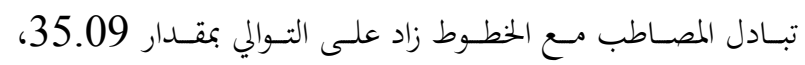

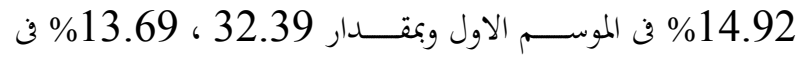

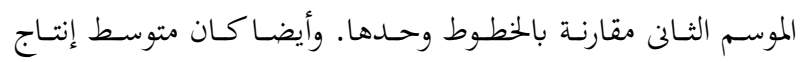

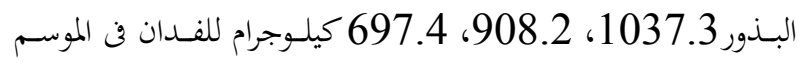

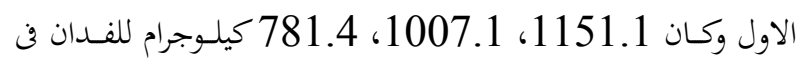
60سم في الموسم الأول والثاني على التوالى.

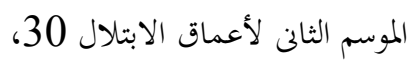

